"Coppice forests: past, present and future"

Editors: Tomáš Vrška, Renzo Motta, Alex Mosseler

\title{
Below- and above-ground biomass, structure and patterns in ancient lowland coppices
}

\author{
Tomáš Vrška ${ }^{(1-2)}$, \\ David Janík ${ }^{(1)}$ \\ Marcela Pálková(1-2), \\ Dušan Adam ${ }^{(1)}$, \\ Jan Trochta ${ }^{(1)}$
}

\begin{abstract}
Introduction
Ancient coppice woods are a specific type of habitat, reflecting long-term human influence and containing high species biodiversity. They conserve local tree ecotypes, and at some sites are the only remnants of original woods with natural species composition, even if the structure of the stands has been modified (Rackham 2006). Coppices demonstrate a vast variability and adaptability in the tree and herb layers and in their processes as a whole (Peterken
\end{abstract}

\begin{abstract}
Ancient coppice woods are areas that reflect long-term human influence and contain high species biodiversity. In this type of forest we aimed to: (i) analyze the below- and above ground biomass of stools and estimate the age of largest stool; (ii) define a "zone of interference" for coppices; (iii) describe and classify variability in the shape and size of coppice stools; (iv) define the specific characteristics of the spatial distribution of stems and stools. The study was conducted in the Podyji National Park, Czech Republic, where two old oak coppice stands were fully stem mapped: Lipina (3.90 ha) and Šobes (2.37 ha). Cores were processed using TimeTable and PAST4. Below- and above-ground biomass of the largest stools was computed using the data from terrestrial laser scanner. Tree zones of influence were analyzed with V-Late landscape analysis tools using Shape Index. The pair correlation function and $L$ function were used to describe the spatial patterns of trees with $\mathrm{DBH} \geq 7 \mathrm{~cm}$, and the null model of Complete Spatial Randomness and Matérn cluster process were tested. For a modeled old stool, we estimated a ratio of 2:1 for above/below ground volume with no reduction of below ground biomass regarding the hollow roots. The age of the largest stool was estimated $825 \pm 145$ (SE) years. An "Inner Zone of Influence" was defined, with a total area covering $323 \mathrm{~m}^{2} \mathrm{ha}^{-1}$. The median area of this zone in both plots was $0.40 \mathrm{~m}^{2}$ for all trees, $0.23 \mathrm{~m}^{2}$ for singles and $0.87 \mathrm{~m}^{2}$ for stools. The Matérn cluster process was successfully fitted to our empirical data. In this model, the mean cluster radius ranged between 1.9 to $2.1 \mathrm{~m}$ and mean number of points per cluster was 1.7 and 1.9. The most prevalent characteristics of these ancient oak coppices were their compact shape and clustered spatial distribution up to $10 \mathrm{~m}$.
\end{abstract}

Keywords: Oak, Stools, Spatial Patterns, Root System, Terrestrial Laser Scanning, Ancient Coppices
1996, Verheyen et al. 1999, Rackham 2006, Schweingruber 2007). Coppicing is considered to be one of the most important ways to manage temperate lowland (oak-dominated) or highland (beech-dominated) woodlands of West and Central Europe, Eastern Asia and North-East America in reserves or urban areas where this kind of management was historically used (Joys et al. 2004, Rackham 2006, Nielsen \& Møller 2008, Itô et al. 2012).

For coppice or coppice with standards
(1) Silva Tarouca Research Institute, Department of Forest Ecology, Lidická 25/27, 60200 Brno (Czech Republic); (2) Faculty of Forestry and Wood Technology, Mendel University in Brno, Department of Silviculture, Zemědělská 3, 61300 Brno (Czech Republic)

@ David Janík (david.janik@vukoz.cz)

Received: Aug 31, 2015 - Accepted: Aug 12, 2016

Citation: Vrška T, Janík D, Pálková M, Adam D, Trochta J (2016). Below- and above-ground biomass, structure and patterns in ancient lowland coppices. iForest 10: 23-31. - doi: 10.3832/ifor1839-009 [online 2016-11-06]

Communicated by: Francesco Ripullone systems, the most common tree species have traditionally been oaks (Quercus sp.), chestnut (Castanea sativa), lindens (Tilia sp.), hornbeam (Carpinus betulus), and beech (Fagus sylvatica), though others have been used as well (Rackham 2006). The main tree species in lowlands is sessile oak Quercus petraea (Matt.) Liebl, a slowergrowing but long-lived deciduous tree species whose wood, bark, acorns and litter have versatile uses. Sessile oak can tolerate a considerable lack of moisture and rocky substrates. Late to leaf, this species is associated with spring geophytes, and natural oak or oak-hornbeam woods are generally considered to host light-demanding spe-

For the purposes of this paper, one or more stems of the same origin creating a single interconnected system were considered as one "tree". Individual stems were designated as "singles", while multistemmed trees as "stools". Stools are formed by clonal stems forming interconnected groups or clusters of individuals that originated through vegetative propagation, such as layering, root suckers, cies of flora and fauna (Dey 2002). 
stolons or stump shoots, from the same parent plant (Kull 1995, Jeník \& Soukupová 1999).

What distinguishes coppiced trees from trees of seed origin is the root and stool system, which can be very old, crooked and extremely large (Peterken 1996, Bauhus 2009). A single coppice stool can have stems several meters away from each other, which nevertheless can be visually identified in the field by experienced observers due to curvatures at the stem bases (Coles 1978) or the typical concentric or linear formations of stems. The age of a stool may be estimated from its diameter; the largest stools are thought to have been continuously coppiced for centuries (Pigott 1989).

Since the mid $19^{\text {th }}$ century, continuous coppicing and the ageing of coppice stools have been blamed for lower stand productivity and quality throughout Europe, and especially for the worsening of soil conditions (Vyskot 1961). However, recent scientific research has not confirmed previous assumptions and has even concluded that in coppice systems, compared to high forests, the decomposition rate and transport of nutrients is faster and soil chemical conditions more favorable, argued to be the consequence of higher light and heat consumption (Hölscher et al. 2001, Bruckman et al. 2011).

Wu et al. (1985) introduced the term "ecological field theory" based on the interactions and interferences among plants. Graded circular zones surrounding individual plants ("influence domain" - Walker et al. 1989 or "zone of influence" - Weber \& Bardgett 2011) were defined. For herbaceous plants, even a Generalized Linear Model concerning the belowground zone of influence has been drawn. This showed that belowground zones of influence are not of fixed circular shapes (Casper et al. 2003). The aim of this paper is to describe and define zones of interference for new seedling recruitment in the case of coppiced trees. Such zones are undoubtedly different from those around trees of seed origin, and for coppiced trees the belowground part is of outstanding importance. We hypothesized that large coppice stools influence the interference potential to a high degree, which a newly germinated seedling would have to overcome to establish itself and successfully grow at a site within the area of a stool.

To describe spatial patterns of stools we used the method of spatial point process analysis, in which the "points" are tree locations and the "marks" tree characteristics such as species, diameter, height, social status etc. (Stoyan \& Penttinen 2000). Due to vegetative reproduction, coppice stands tend to be characterized by high clumping intensities at small spatial scales, i.e., clustered formations. The size and shape of the stool cluster could therefore also be characteristic for different tree species or ecotope conditions, such as terrain exposition, and they play a significant role in determining the age of the stool, in other words the length of continuous human activity - coppicing. Therefore, we also attempted to better define the specific characteristics of the stems and stools in ancient coppices.

To better understanding the structure and patterns in ancient coppices both below and above ground, we asked the following questions: (i) what is the ratio of below- and above-ground structure and biomass of ancient Central European coppices and how old are the largest stools? (ii) What is size of "zone of interference" for coppices - the area around every tree (stool) that is practically inaccessible for

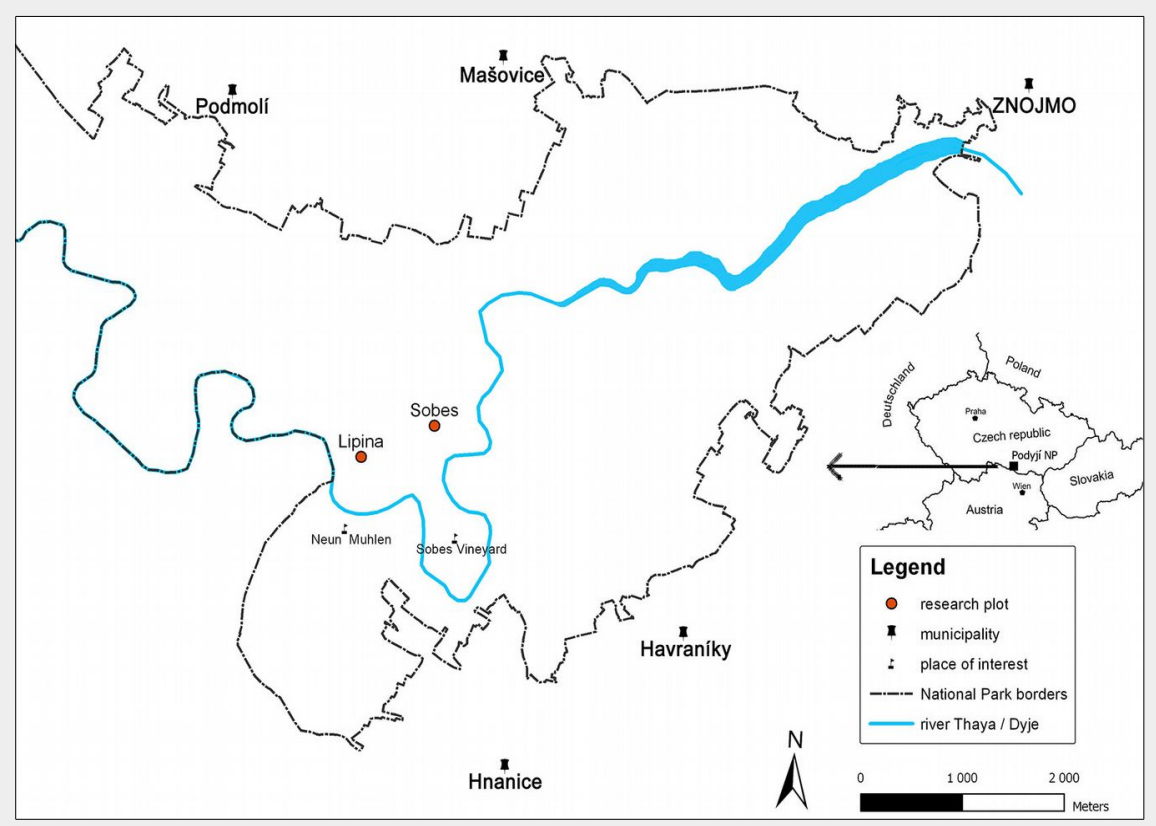

Fig. 1 - Location of the research plots within the Podyjí National Park (Czech Republic). natural seed regeneration? (iii) What is the variability in the shape and size of coppice stools? (iv) What are the specific characteristics of the spatial distribution of stems and stools in ancient coppices?

\section{Material and methods}

\section{Study site}

We studied long-abandoned, sessile oak (Quercus petraea) dominated ancient coppices in the Podyjí National Park (hereafter PNP), Czech Republic. Average yearly temperature in the PNP is between 8 and $9{ }^{\circ} \mathrm{C}$, and average precipitation $550-600 \mathrm{~mm}$ (Tolasz 2007). In a biogeographical sense, the PNP lies in the transition zone between the Hercynian and Pannonian provinces (the mesophytic and the thermophytic) that, together with the varied morphology of the river valley and the plateaux, creates high species diversity (Chytry \& Vicherek 1995). The PNP is among the longest settled areas in Central Europe, and has been continuously inhabited since 5-6000 BC (Neruda 2007). The forest history in the PNP has been described by Vrška (1998), and Reiterová \& Skorpík (2012). Woodlands in the PNP were intensively influenced by deforestation, pasture, burning, litter raking, cultivation terraces and coppicing.

Two research plots, Lipina ( 3.90 ha $-48^{\circ}$ $49^{\prime} 19^{\prime \prime} \mathrm{N}, 15^{\circ} 57^{\prime} 47^{\prime \prime} \mathrm{E}$ ) and Šobes (2.37 ha $48^{\circ} 49^{\prime} 32^{\prime \prime} \mathrm{N}, 15^{\circ} 58^{\prime} 21^{\prime \prime} \mathrm{E}$ - Fig. 1), are located in the core (non-intervention) zone of the PNP. Lipina lies on the eastern side of the National Park with an average inclination of $20^{\circ}$ and elevation ranging between 300-365 $\mathrm{m}$ a.s.l. Šobes lies on the transition ridge between the valley and the plateau, and has more moderate slopes at elevations between 382-395 $\mathrm{m}$ a.s.l. The geological bedrock at both sites consists of granites and similar rocks of Proteozoic to Paleozoic age (Reiterová \& Skorpík 2012). The vegetation and soil conditions at Lipina were described in Janík et al. (2007). The ancient coppices at Lipina, Šobes and other stands in the PNP were left unmanaged after active coppicing started to be abandoned at the end of $19^{\text {th }}$ century and definitively ceased in the 1950 s.

\section{Stool mapping and biomass computation}

Tree and stand data were acquired using Field-Map ${ }^{\circledast}$ technology (Jilove u Prahy, (zech Republic), with a MapStar compass module, laser rangefinder, Impulse altimeter (Laser Technology) and Hammerhead field computer (WalkAbout Computers http://www.fieldmap.cz/). All standing and lying trees with diameter at breast height $(\mathrm{DBH}) \geq 7 \mathrm{~cm}$ and stumps with diameter at the base $\geq 7 \mathrm{~cm}$ were measured, and stem position maps were constructed for Lipina in 2006 (Janík et al. 2007) and for Šobes in 2010. For standing stems the following categories were distinguished: live normal, live breakage - snap, full dead stem and snag. Lying deadwood was measured and 
classified into three stages of decay: hard, touchwood and disintegrated (Král et al. 2014). For growing shape construction the heights were measured for $10 \%$ of standing stems. Height curves were constructed using the Naeslund's function. During fieldwork in 2010, every standing stem and stump was classified as a single or part of a stool, and the affiliation of stems to stools was recorded in the database using unique IDs for each stool.

In 2010, we exposed the root systems of three old stools of different sizes and shapes (Fig. 2). Unearthing was performed manually using hand tools, pneumatic drills and an air-spade supersonic nozzle (Nadezhdina \& (ermak 2003). We removed the earth to the underlying bedrock at a maximum depth of $65 \mathrm{~cm}$. Exposing the root and stool systems served as a basis for the assessment and mapping of these stools by terrestrial laser scanning. Each uncovered stool was scanned from 9 different positions to record all shapes. After merging all scans into a single one, the resulting point cloud was used to create a model of a stool and its stems (Fig. 2a) for estimating biomass and stem positions. A Leica ScanStation $\mathrm{C}_{10}{ }^{\mathrm{TM}}$ (Leica Geosystems, Heerbrugg, Switzerland) was used for scanning, together with Cyclone ${ }^{\circledR}$ software for merging single scans, and exported to ASCII file. From the ASCII data, the model of stems, branches and roots was created using Geomagic Studio $2014^{\circledR}$ software (3D Systems, Rock Hill, SC, USA). A closed manifold surface of all stems and roots that were recognized in stools was generated, and the volume of each part was estimated and a planar projection of each tree and the whole stool was created.

\section{Stand age analysis and stool age estimation}

To survey the age structure of living stems, we sampled the research plots for dendrochronological analysis with an increment borer in 2010. On the basis of stem position maps, we created a regular square network of $44.25 \mathrm{~m}$. At each network point the 2-3 closest live stems were cored. We collected 115 increment cores of individual stems (Lipina: 72; Šobes: 43). The cores were processed using the software packages TimeTable and PAST4 (http://www. sciem.com/products/past/) with an accuracy of $0.01 \mathrm{~mm}$. To extrapolate the age of cores bored off-pith, missing tree rings were calculated from the measured distance to the estimated pith with a compass and the average width of the first five measured tree rings. Only cores with a maximum of 6 extrapolated tree rings were included into the age analyses (Lipina: 38 ; Šobes: 26).

For stool age ( $S A$ ) estimation we used the following formula (eqn. 1):

$$
S A=A G R^{-1} \cdot D S R+A A S-20
$$

where $A G R$ is the average growth rate

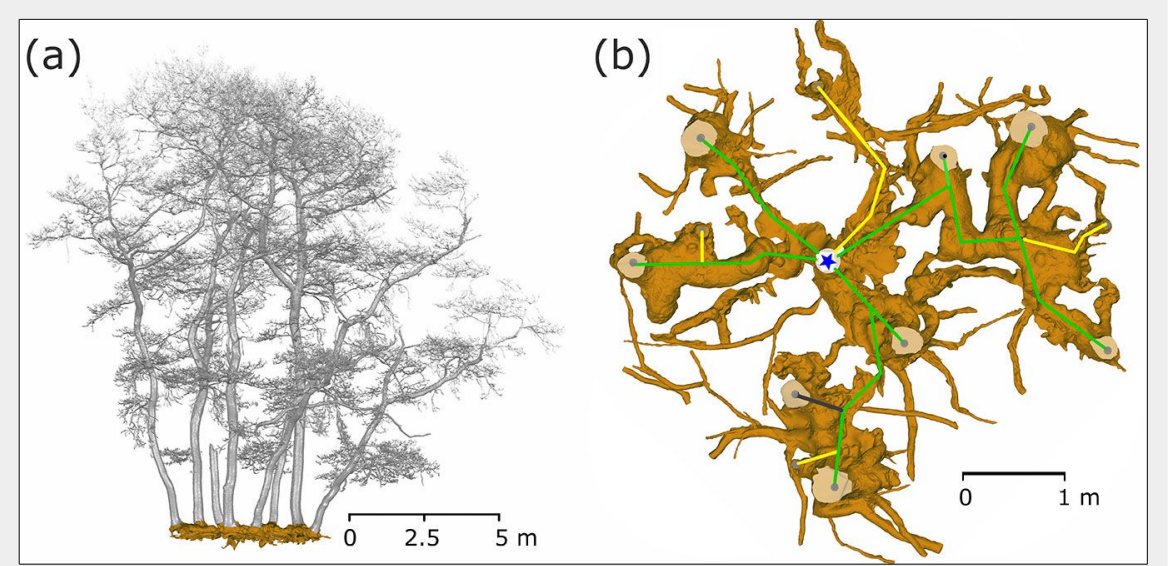

Fig. 2 - Exposed coppice stool root system (Lipina research plot). The current state was captured by a terrestrial laser scanner and saved as a mesh for further analysis. In part (a) the stems are visualized as a side view of the single stool with the whole root system (brown) as a realistic model. A detailed root system model (b) shows all coarse roots, the positions of the living stems (grey dots on stem profiles) and their connections (green - living trees; yellow - historical stumps; grey - standing snags) to the origin (blue star) of the stool.

based on annual radial increment, DSR is the average distance of current stems from the parent central root (Fig. 2b), and $A A S$ is the average age of current stems minus 20 as the age used for the $A G R$. $A G R$ is based on the radial growth of individual stems (shoots), which is simultaneous with the growth of the stool radius; therefore, the growth rate of the entire stool should be twice the radial increment measured on shoots. In practice, the real rate of radius growth of the stool cluster is not twice the mean annual radial growth but is rather somewhat smaller. The reason behind this is that the ground plan projection of the stem circumference is an "inclined plane". New coppice shoots always spread outwards from the original stump, but because of space restrictions by the original stump, they bend as they grow larger, creating stem curvature at the base and oblique growth. Based on Pigott (1989), we used a coefficient rate of 1.8 of the mean width increment.

Based on forest management plans from the beginning of the 2oth century (Vrška 1998), we established that the rotation period at our research plots was intended to be 40 years. Older written material was not so detailed, but previous research has demonstrated that the further one goes back in time, the shorter the coppice cycle tended to be. For instance, in the Middle Ages coppicing was done every seven to ten years (Rackham 2006). A twenty-year period was chosen as a long-term average rotation period. According to the historical surveys, the $A G R$ was calculated as the average radial increment of the first 20 tree rings from the dendrochronological analysis of the entire research plot.

$D S R$ was calculated using the 3D model of the stool root and standard image analysis.

\section{Tree inner zone of influence}

In order to determine the tree interference zone (i.e., the area practically inaccessible for the successful establishment and growth of tree seedlings), we defined the Tree Inner Zone of Influence (Tree ${ }_{|z|}$ ). Tree IzI $_{12}$ is a closed polygonal area which constituted a projection of (i) the basal area(s) of standing stem(s) or stump(s), (ii) a buffer(s) around the basal area(s), and, in the case of stools, (iii) the stool polygon and (iv) a buffer around the polygon (Fig. 3). The circumference of the stool polygon was created as a link among standing stems or stumps through a procedure of searching nearest neighbors in the stool such that (i) all stems or stumps should lie inside the polygon, and (ii) the circumference line should go directly through each stem or stump position (i.e., a convex hull of stems positions). The buffer size (BS) around each stem or stump was determined by linear scaling according to the diameter (DBH). For smaller trees the buffer radius is a little larger than $\mathrm{DBH}$, while larger trees have a buffer radius almost equal to the $D B H$ value (eqn. 2 ):

\section{$B S=0.85 \cdot D B H+7.386$}

For the circumference, the line of stool buffers with $r=$ the mean diameter of stool was used. Variability analysis and categorization of Tree ${ }_{1 z \mid}$ shapes were carried out with the landscape analysis tool V-Late (Lang \& Tiede 2003) using the Shape Index (eqn. 3):

$$
\text { SHAPE }=\frac{P_{i j}}{\min P_{i j}}
$$

where $P_{\mathrm{ij}}$ is the the perimeter of patch $i j$ in terms of the number of cell surfaces and $\min P_{\mathrm{ij}}$ is the minimum perimeter of patch $i j$ in terms of the number of cell surfaces. The Shape Index (SI) is a dimensionless ex- 


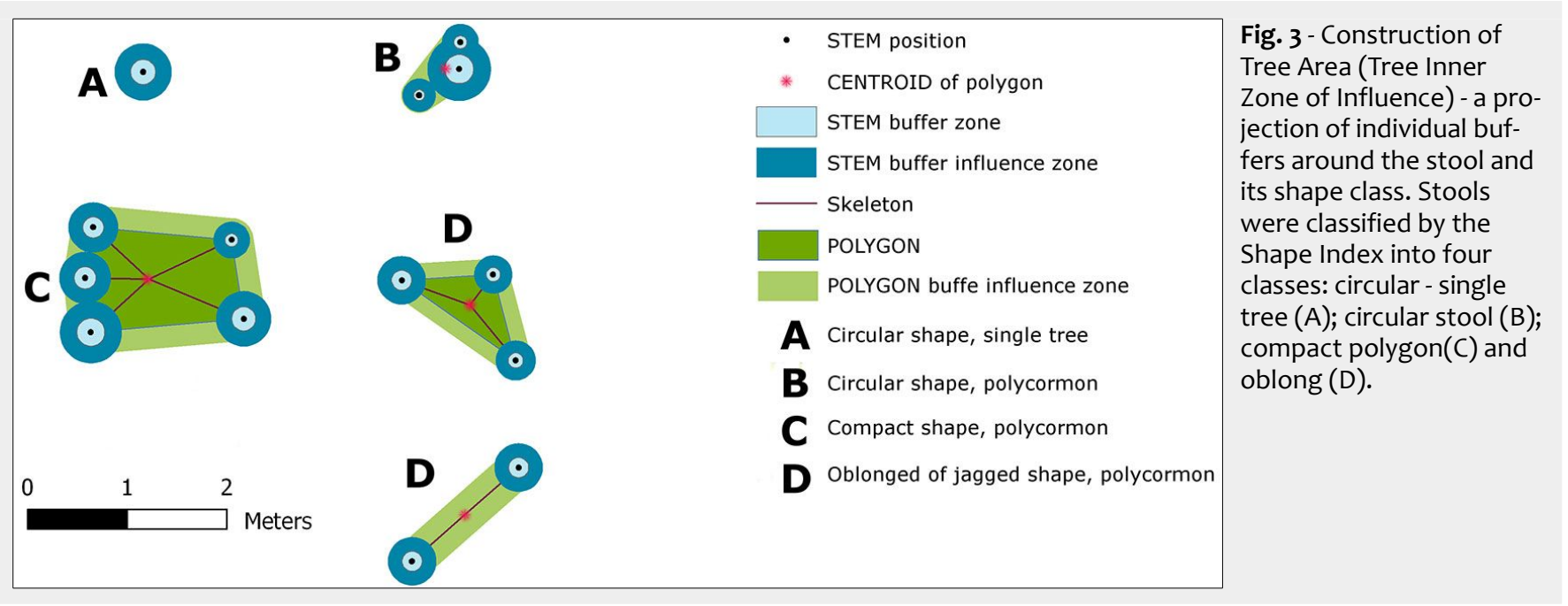

pression of compactness. Maximum compactness is represented by a circle; with increasing complexity, crookedness or jaggedness $\mathrm{SI}$ also increases. The range of $\mathrm{SI}$ is $\geq 1$, and is without limit. The V-Late ArcGIS ${ }^{\circledR}$ extension is an implementation of procedures based on Fragstat (McGarigal \& Marks 1995).

\section{Tree spatial patterns}

To describe the density variability of both individual standing stems and stumps, we used the univariate pair correlation function. The pair correlation function is a second order characteristic, as are the frequently used $K$ function (Ripley 1977) and $L$ function (Besag 1977). Stoyan \& Penttinen (2000) define the pair correlation function as follows: consider two infinitesimally small discs of areas $d x$ and $d y$ at distance $r$. Let $p(r)$ denote the probability that each disc contains a point of the process. Then $p(r)=\lambda 2 g(r) d x d y$, where $\lambda$ is density. Put in a different way, the pair correlation function $g(r)$ is the probability of observing a pair of points separated by a distance $r$, divided by the corresponding probability for a Poisson process (Baddeley 2008). It is related to the $K$ function by (eqn. 4 ):

$$
g(r)=\frac{d}{d r} \cdot \frac{K(r)}{2 \pi r} \quad \text { for } r \geq 0
$$

The essential difference between the $K$ function and the pair correlation function is the non-cumulative character of the latter. The pair correlation function uses annuli as distance classes, not circles. Under the assumption of a homogenous Poisson process, $g(r)=1$. Values of $g(r)$ larger than one indicate clustering, while values smaller than one indicate regularity. The pair correlation function $g(r)$ was estimated for each plot at steps of $1 \mathrm{~m}$ for $r$-values up to $20 \mathrm{~m}$. A null model of complete spatial randomness (hereafter CSR) was used on the assumption that the first-order intensity $\lambda$ is constant within plots. For the fixed value of $r$ we used 199 Monte Carlo simulations of CSR to obtain pointwise critical envelopes for $g(r)$. The significance level of tests was 0.01. A fixed $r$ had to be chosen prior to the simulation, since if all $r$ values are considered simultaneously, the probability of rejecting $\mathrm{H}_{0}$ increases and the true

Tab. 1 - Main tree layer parameters at Lipina and Šobes.

\begin{tabular}{|c|c|c|c|c|c|}
\hline Layer & Parameter & Decay stage & Units & Šobes & Lipina \\
\hline- & area & - & ha & 2.37 & 3.90 \\
\hline Live Standing & stem no. & - & $\mathrm{N} \mathrm{ha}^{-1}$ & 634 & 642 \\
\hline \multirow{2}{*}{ Trees } & basal area & - & $\mathrm{m}^{2} \mathrm{ha}^{-1}$ & 32.0 & 29.6 \\
\hline & timber volume & - & $\mathrm{m}^{3} \mathrm{ha}^{-1}$ & 262.0 & 263.0 \\
\hline \multirow{3}{*}{$\begin{array}{l}\text { Dead Standing } \\
\text { Trees }\end{array}$} & stem no. & - & $\mathrm{N} \mathrm{ha}^{-1}$ & 59 & 121 \\
\hline & basal area & - & $\mathrm{m}^{2} \mathrm{ha}^{-1}$ & 1.3 & 2.6 \\
\hline & timber volume & - & $\mathrm{m}^{3} \mathrm{ha}^{-1}$ & 7.6 & 16.7 \\
\hline \multirow[t]{2}{*}{ Stumps } & stem no. & - & $\mathrm{Nha}^{-1}$ & 271 & 41 \\
\hline & basal area & - & $\mathrm{m}^{2} \mathrm{ha}^{-1}$ & 8.8 & 1.1 \\
\hline \multirow{8}{*}{$\begin{array}{l}\text { Dead lying } \\
\text { stems }\end{array}$} & stem no. & $\mathrm{H}$ & $\mathrm{N} \mathrm{ha}^{-1}$ & 16 & 47 \\
\hline & & $\mathrm{T}$ & $\mathrm{Nha}^{-1}$ & 32 & 245 \\
\hline & & $\mathrm{D}$ & $\mathrm{N} \mathrm{ha}^{-1}$ & 1 & 12 \\
\hline & & Total & $\mathrm{N} \mathrm{ha}^{-1}$ & 49 & 304 \\
\hline & timber volume & $\mathrm{H}$ & $\mathrm{m}^{3} \mathrm{ha}^{-1}$ & 2.5 & 12.0 \\
\hline & & $\mathrm{T}$ & $\mathrm{m}^{3} \mathrm{ha}^{-1}$ & 4.6 & 43.0 \\
\hline & & $\mathrm{D}$ & $\mathrm{m}^{3} \mathrm{ha}^{-1}$ & 0.1 & 1.0 \\
\hline & & Total & $\mathrm{m}^{3} \mathrm{ha}^{-1}$ & 7.2 & 56.0 \\
\hline
\end{tabular}

error probability is larger (Loosmore \& Ford 2006). Therefore, if we had estimated continuous intervals of the distances over which an observed pattern deviates from the hypothesized model, the results could not have been considered significant with a significance level of 0.01 .

A cluster process model was also fitted to the data as an alternative to the Poisson homogenous process. We used the Matérn cluster process, in which the parent points come from a homogeneous Poisson process with intensity $\kappa$, and each parent has a Poisson number $(\mu)$ of offsprings, independently and uniformly distributed in a disc of radius $\mathrm{R}$ centered on the parent (Baddeley 2008). We used the $L$ function as summary statistics for fitting the model to the data. To determine the values of the parameters that achieve the best match between the fitted $L \Theta(r)$ and the empirical $L$-function of the data, we used the method of minimum contrast (Diggle 2003). Since maps of individual plant locations cannot be used to investigate processes occurring at scales that approach the accuracy of the measurements (Freeman \& Ford 2002), and our spatial error was $\pm 1.1 \mathrm{~m}$, we focused primarily on large-scale processes, such as clustering. All spatial analyses were conducted using the package "spatstat" (Baddeley \& Turner 2005) in the statistical software R (R Development Core Team 2015).

\section{Results}

Below- and above-ground biomass and coppice stand structure

The basic characteristics of the tree layer at Lipina and Šobes are shown in Tab. 1. Approximately 640 live standing stems per hectare represented a timber stock of about $260 \mathrm{~m}^{3} \mathrm{ha}^{-1}$ and a basal area of ca. 30 $\mathrm{m}^{2} \mathrm{ha}^{-1}$. The number of stumps (mostly of artificial origin) was 41 ha $^{-1}$ at Lipina and 271 $\mathrm{ha}^{-1}$ at Šobes. The median diameter of stems and stumps was $22 \mathrm{~cm}$ at both plots, but at Šobes there were more thick individuals (Fig. 4). Long-term coppicing significantly altered the forest structure and tex- 
Fig. 4 - Diameter distribution of standing stems and stumps at Lipina and Šobes.

ture. The majority of stems and stumps were growing in stools; in total, only ca. $25 \%$ were single-stemmed trees (Tab. 2). At Šobes there were proportionally more multi-stemmed trees (stools with 4 and more stems or stumps), but two- and three-stemmed stools still predominated (Fig. 5).

The average upper height of the stand was about 18 meters at both plots. A distinctive difference between the plots was found for deadwood volume, which was more than 4 times higher at Lipina than at Šobes (73 and $15 \mathrm{~m}^{3} \mathrm{ha}^{-1}$, respectively). The dynamics of changes in the tree layer was more pronounced at Lipina, while at Šobes larger gaps in the crown canopy were missing because of the smaller number of fallen dead trees, which were also less disintegrated than at Lipina.

From the modeled stool, above and below ground biomass was calculated. The below ground biomass of the stool was estimated to be $1.02 \mathrm{~m}^{3}$ of woody biomass connecting 7 living stems and one snag, and the sum of the above ground biomass was about $2.13 \mathrm{~m}^{3}$. The stool had a planar

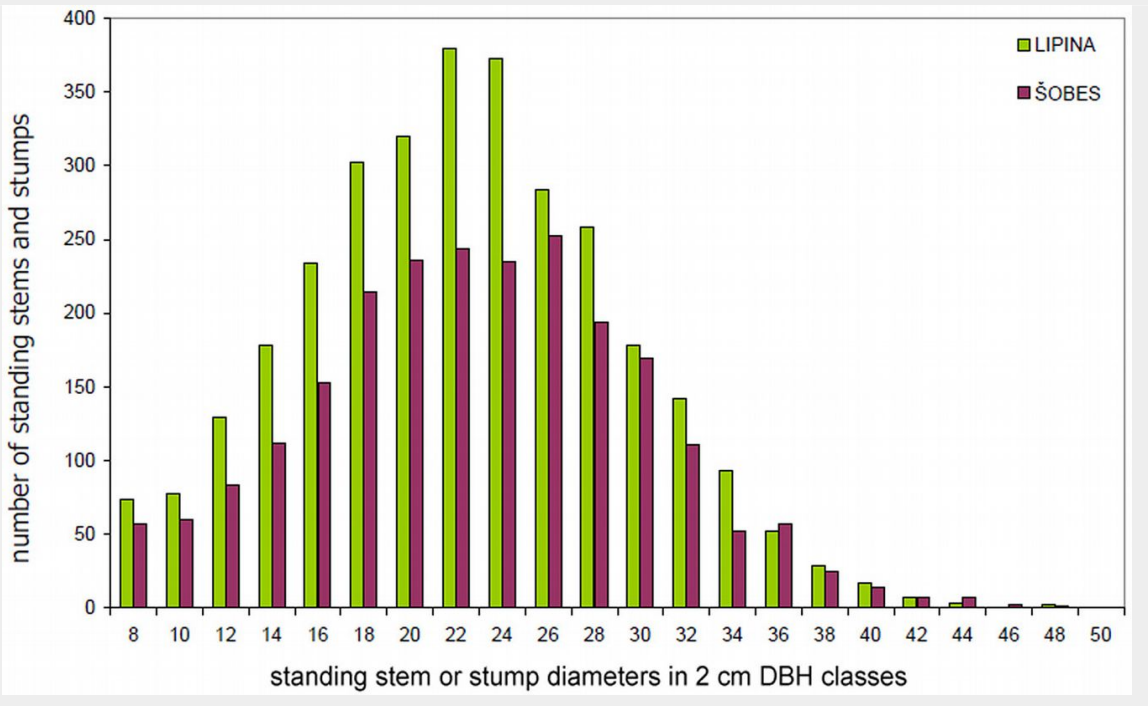

Tab. 2 - Numbers and densities of single and multi-stemmed trees (stools), and coverage of the Tree Inner Zone of influence.

\begin{tabular}{|c|c|c|c|c|c|}
\hline Group & Parameter & Units & Šobes & Lipina & Total \\
\hline- & Plot Area & ha & 2.4 & 3.9 & 6.3 \\
\hline \multirow{6}{*}{$\begin{array}{l}\text { Standing single } \\
\text { stems and } \\
\text { stumps }\end{array}$} & \multirow[t]{2}{*}{ stools } & $\mathrm{N}$ & 1841 & 2298 & 4139 \\
\hline & & $\mathrm{N} \mathrm{ha}^{-1}$ & 777 & 589 & 660 \\
\hline & \multirow[t]{2}{*}{ singles } & $\mathrm{N}$ & 444 & 834 & 1278 \\
\hline & & $\mathrm{N} \mathrm{ha}^{-1}$ & 187 & 214 & 204 \\
\hline & \multirow[t]{2}{*}{ total } & $N$ & 2285 & 3132 & 5417 \\
\hline & & $\mathrm{N} \mathrm{ha}^{-1}$ & 964 & 803 & 864 \\
\hline \multirow{10}{*}{$\begin{array}{l}\text { Trees } \\
\text { (tree zone of } \\
\text { inner influence) }\end{array}$} & \multirow[t]{3}{*}{ stools } & $N$ & 496 & 820 & 1316 \\
\hline & & $\mathrm{m}^{2}$ & 768 & 940 & 1708 \\
\hline & & $\mathrm{m}^{2} \mathrm{ha}^{-1}$ & 324 & 241 & 272 \\
\hline & \multirow[t]{3}{*}{ singles } & $N$ & 444 & 834 & 1278 \\
\hline & & $\mathrm{m}^{2}$ & 116 & 199 & 315 \\
\hline & & $\mathrm{m}^{2} \mathrm{ha}^{-1}$ & 49 & 51 & 50 \\
\hline & \multirow[t]{4}{*}{ total } & $N$ & 940 & 1654 & 2594 \\
\hline & & $\mathrm{m}^{2}$ & 884 & 1139 & 2023 \\
\hline & & $\mathrm{N} \mathrm{ha}^{-1}$ & 397 & 424 & 414 \\
\hline & & $\mathrm{m}^{2} \mathrm{ha}^{-1}$ & 373 & 292 & 323 \\
\hline
\end{tabular}

projection area of $122.35 \mathrm{~m}^{2}$ with an aver- Stand age and stool age

age stem planar projection area of $26.4 \mathrm{~m}^{2}$. According to the dendrochronological The uncovered area and the root system analyses, forest stands at the research had an area of about $20 \mathrm{~m}^{2}$.

Fig. 5 - Frequency distribution of the number of stems or stumps in one stool.

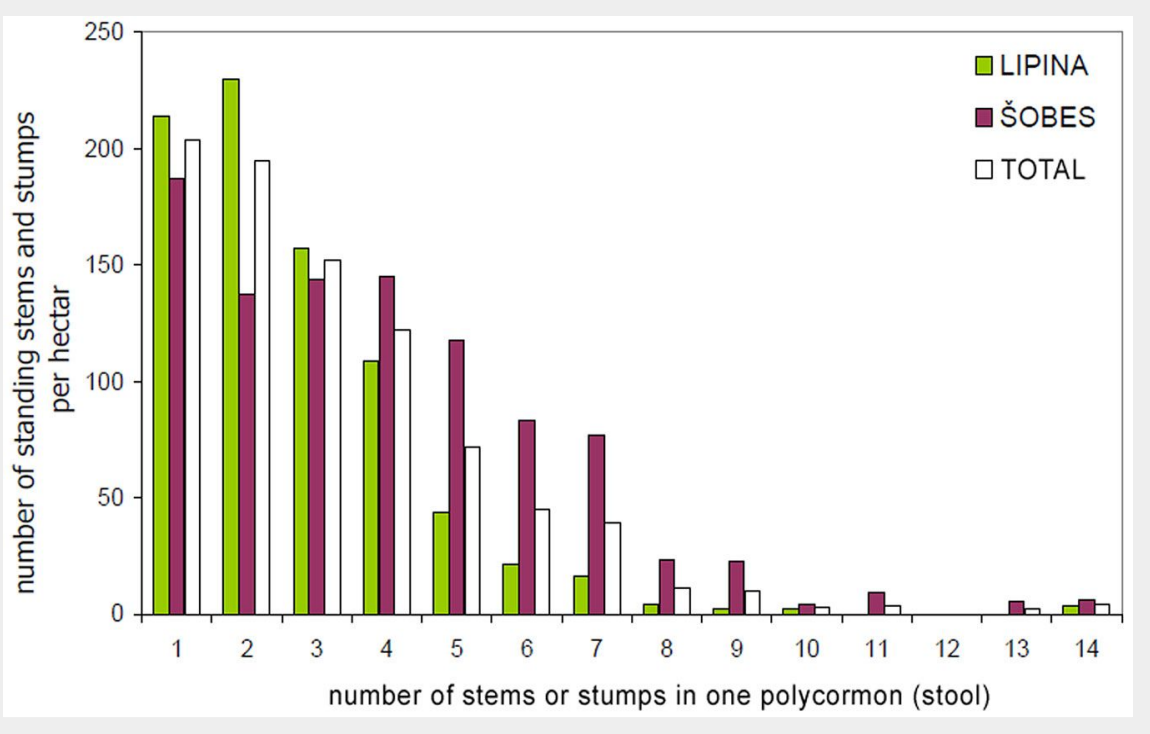




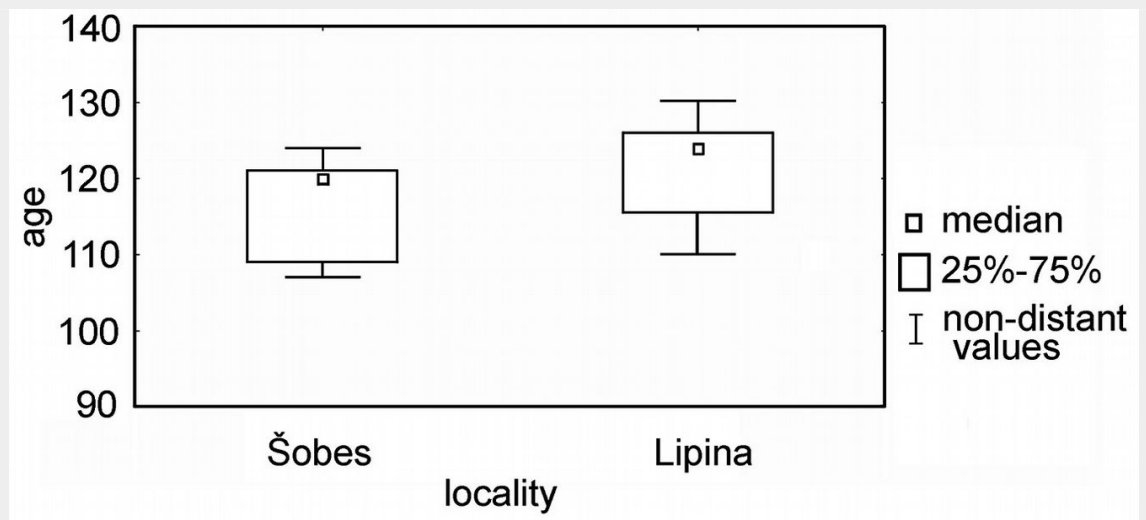

Fig. 6 - Box plot of age distributions at the Lipina and Šobes sites.
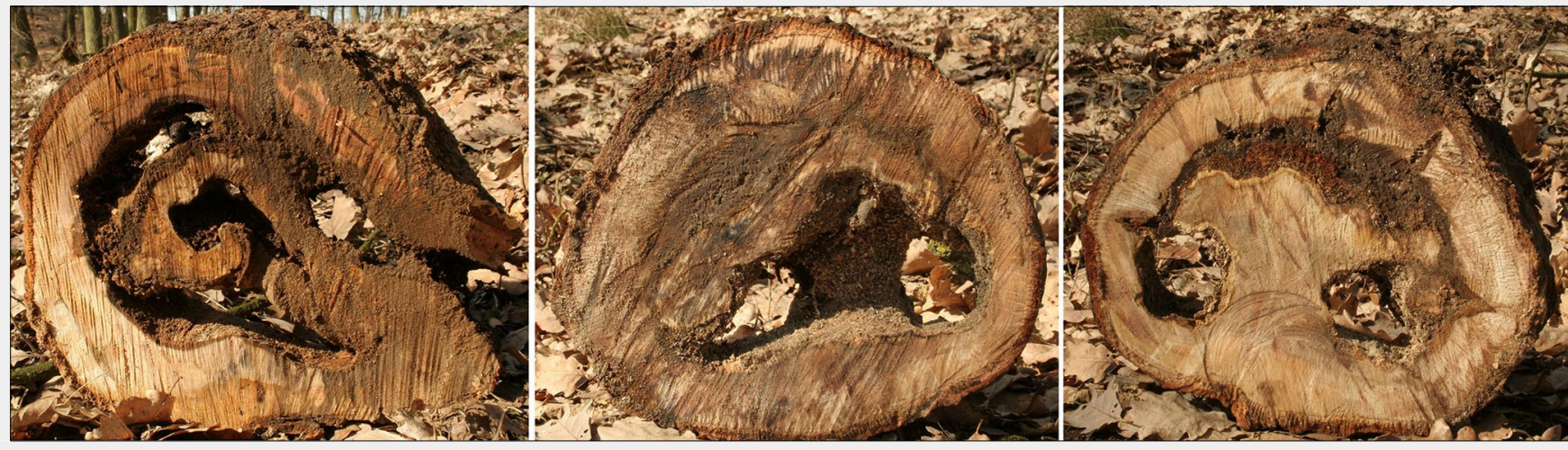

Fig. 7 - Stool root profile - internal cambium created in the root cavity.

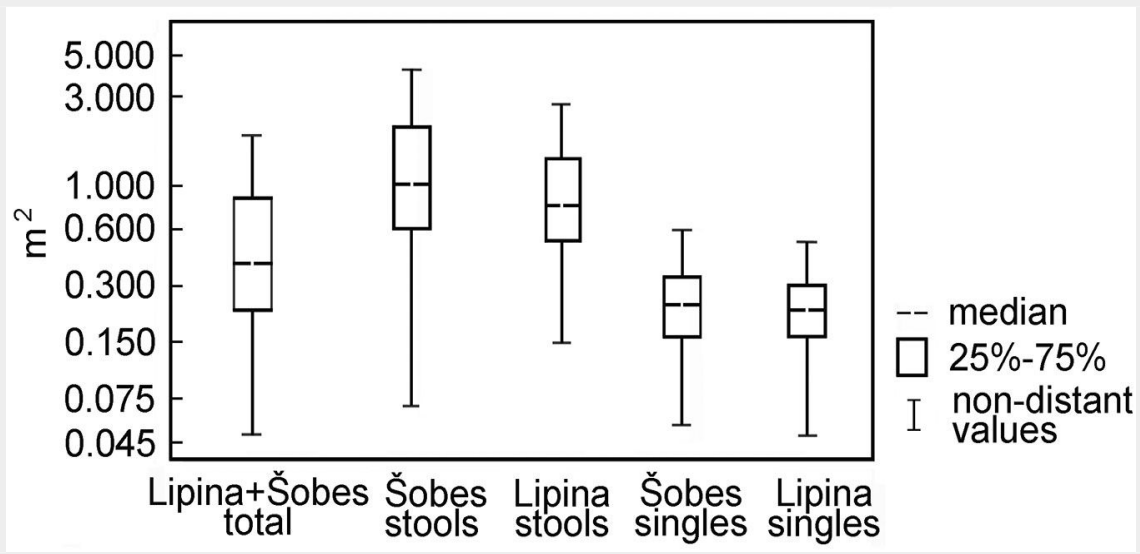

Fig. 8 - Total tree area (Tree Inner Zone of Influence) for single trees and trees in stools. The box plots show the range of area for single trees and stools in the study plot.

and 1890 (Šobes). The measured mean War II, and sporadically since the 1950 s. stem age was 124 years at Lipina $\left(Q^{25-75}: 116-\right.$ During the $1980 \mathrm{~s} / 90 \mathrm{~s}$, Šobes was thinned $126 \mathrm{yrs}$ ) and 120 years at Šobes ( $\mathrm{Q}^{25-75}: 109$ - as part of a planned transformation into 122 yrs - Fig. 6). Spot felling could be high forest, and the number of stems in detected small-scale thinning at Lipina; stumps from these thinnings can still be easily recognized in the forest, and almost none has re-sprouted with new shoots.

traced during the Great depression, World one stool was partially reduced. We also

The largest stool (Fig. 2b) had an average

Tab. 3 - Shape types and tree types according to the Shape Index, along with basic characteristics of the Tree Inner Zones of Influence. (NP): number of patches; (MPS): mean patch size; (PSSD): PS standard deviation; (MSI): mean shape index.

\begin{tabular}{|c|c|c|c|c|c|c|c|c|c|c|c|c|c|}
\hline \multirow[t]{2}{*}{ Class } & \multirow[t]{2}{*}{ Shape type } & \multirow{2}{*}{$\begin{array}{l}\text { Tree } \\
\text { type }\end{array}$} & \multirow[t]{2}{*}{ Criterion } & \multicolumn{2}{|c|}{$\begin{array}{l}\mathrm{NP} \\
\left(\mathrm{N} \mathrm{ha}^{-1}\right)\end{array}$} & \multicolumn{2}{|c|}{$\begin{array}{l}\text { Class Area } \\
\left(\mathrm{m}^{2} \mathrm{ha}^{-1}\right)\end{array}$} & \multicolumn{2}{|l|}{$\begin{array}{l}\text { MPS } \\
\left(m^{2}\right)\end{array}$} & \multicolumn{2}{|l|}{ PSSD } & \multicolumn{2}{|l|}{ MSI } \\
\hline & & & & Šobes & Lipina & Šobes & Lipina & Šobes & Lipina & Šobes & Lipina & Šobes & Lipina \\
\hline I & circular & single & $\mathrm{SI} \leq 1.001$ & 187 & 214 & 49 & 51 & 0.26 & 0.24 & 0.12 & 0.11 & 1.001 & 1.001 \\
\hline 1 & circular & stool & $\mathrm{SI} \leq 1.075$ & 13 & 10 & 10 & 5 & 0.82 & 0.46 & 0.98 & 0.18 & 1.054 & 1.038 \\
\hline II & compact & stool & $1.075<\mathrm{SI} \leq 1.285$ & 167 & 149 & 251 & 174 & 1.5 & 1.17 & 1.18 & 0.97 & 1.171 & 1.186 \\
\hline III & elongated or jagged & stool & $\mathrm{SI}>1.285$ & 29 & 52 & 62 & 62 & 2.14 & 1.2 & 2.21 & 1.31 & 1.367 & 1.363 \\
\hline Total & - & - & - & 396 & 424 & 372 & 292 & - & - & - & - & - & \\
\hline
\end{tabular}



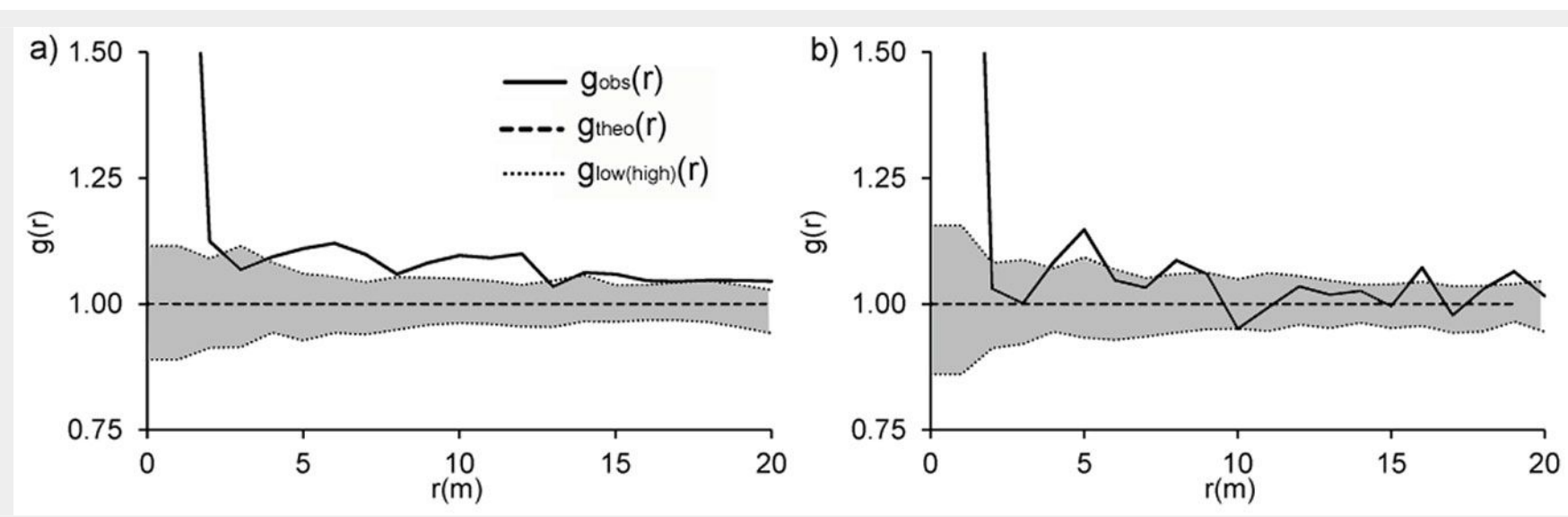

Fig. 9 - Pair correlation functions $g(r)$ show spatial patterns of all stems at Lipina (a) and Šobes (b). $g_{\text {obs }}(r)$ : observed function; $g_{\text {theo }}(r)$ : theoretical value for complete spatial randomness; $g_{\text {low(high) }}(r)$ : pointwise envelopes resulting from 199 Monte Carlo simulations of the null model of complete spatial randomness. When $g_{\text {obs }}(r)>g_{\text {high }}(r)$, a positive association between stems is suggested, while $g_{\text {obs }}(r)<g_{\text {low }}(r)$ suggests a negative association of stems. In the grey zone, the null hypothesis of complete spatial randomness cannot be rejected. The variable " $r$ " refers to distance.

distance of $2.13 \pm 0.3 \mathrm{~m}(\mathrm{SE})$ and an average annual radial increment of $1.46 \pm 0.06$ $\mathrm{mm}$. The age of this stool was $825 \pm 145$ years, which means that the stool originated in the $11^{\text {th }}-13^{\text {th }}$ centuries (High Middle Ages). Older roots were often hollow inside and we observed a secondary growth of cambium into this hollow space (Fig. 7). This obviously rules out any age analysis.

\section{Tree inner zone of influence}

Tree Inner Zone of Influence (Tree ${ }_{|z|}$ ) area covered $292 \mathrm{~m}^{2}$ ha-1 at Lipina and $372 \mathrm{~m}^{2} \mathrm{ha}^{-1}$ at Šobes (mean: $323 \mathrm{~m}^{2} \mathrm{ha}^{-1}$ ). The median area of Tree $1 z 1$ for a full set of both plots was $0.40 \mathrm{~m}^{2}$ for all trees, $0.23 \mathrm{~m}^{2}$ for singles and $0.87 \mathrm{~m}^{2}$ for stools. At Šobes the Interquartile Range of Tree $_{|z|}$ values was wider compared with Lipina (Fig. 8), and the occurrence of larger stools $\approx$ larger Tree $_{\text {Izl }}$ was more frequent. While the distribution of stem and stump diameters tended to be normal or normal related, the distribution of Tree $_{|z|}$ area was strongly positively skewed and best fit with extreme values or lognormal distribution even if very few large stools composed a relatively large total of the Tree ${ }_{|z|}$ area.

For a basic differentiation of the variety of Tree ${ }_{\mathrm{Izl}}$ areas, we used the Shape Index (SI). Based on the results, we defined three categories of Tree $\mathrm{I}_{\mathrm{II}}$ shapes: (I) rounded; (II) compact; (III) jagged (Tab. 3, Fig. 3), by comparing to the boundary values of SI for the basic, mathematically easily definable shapes of a pentagon $(\mathrm{SI}=1.075)$ and equilateral triangle $(\mathrm{SI}=1.285)$. Both in numbers and area, the most prevalent was category II (compact - Tab. 3). Mean patch size at Lipina was smaller than at Šobes for all categories, most significantly in category III (jagged). In general, for our data raising $\mathrm{Sl}$ raises the patch size of Tree ${ }_{\mathrm{Izl}}$ (Pearson's $r=0.4856$; significance of $\mathrm{F}$ for regression analysis: $\mathrm{p}<0.0001$ ).

\section{Tree spatial patterns}

Our evaluation of the spatial distribution of all standing stems and stumps (both singles and stools) resulted in slight differences between the two plots (Fig. 9). While at Lipina stems and stumps were significantly clustered over all examined distances (Fig. 9a), at Šobes for the majority of distances complete spatial randomness (CSR) could not be rejected, and a significantly clustered distribution was confirmed only for individual distances $(1,4,5,8,16$ and $19 \mathrm{~m}$ - Fig. $9 \mathrm{~b}$ ). Since the CSR hypothesis was rejected for the distribution of trees at Lipina and partly at Šobes, the Matérn cluster process was fitted to our empirical data. The minimum contrast method based on the $L$ function yielded the estimates $R=2.11 \mathrm{~m}$ (cluster radius), $c=$ 1.85 (mean number of points per cluster) and intensity $\kappa=0.04 \mathrm{~m}^{-2}$ for Lipina stems and $R=1.22 \mathrm{~m}, c=1.68$ and $\kappa=0.05 \mathrm{~m}^{-2}$ for stems at Šobes. The empirical $L$ function and envelopes from 199 simulations of the fitted model showed good agreement for Šobes trees in particular.

\section{Discussion}

\section{Ancient stool roots and age}

Because roots are generally less accessible and more difficult to explore and measure, they are less well known than the aboveground parts of plants. A detailed morphological and anatomic analysis of root systems can potentially indicate relationships between roots, the outside environment and other organisms at a particular site. The analysis of root systems, especially in the case of older individuals, can be used to gain insights into the complex and long-term driving factors influencing individual stands. The analysis of roots of oak on skeletal soils have shown that in such conditions trees sometimes develops distorted plates or slats, which are pushed into the small spaces between rocks or fis- sures of the parent rock (Jeník 1957, Schweingruber 2007). Oak tree rings are visible only in root ends and adjacent areas of surface skeletal roots, which also show other signs of transitional anatomy between aboveground and underground organs (Jeník 1957, Bédéneau \& Pagés 1984). As a result, dendrochronological cores of old roots cannot be used to determine the age of ancient coppice stools.

Structural differences in wood anatomy are more variable for broadleaf trees than for conifers (Gaertner 2001), making it much more difficult to detect changes in the wood in response to various events. Because the influences of climate, stand density, and social position of a tree causes large variability in ring width pattern, Copini et al. (2010) rejected to use the patterns of wide rings around the pith, previously utilized by Haneca et al. (2005, 2009) as a fingerprint of coppice management. Our findings are in agreement with these views.

To examine the age of ancient stools and the processes that led to their current shape, one must go beneath the surface to uncover the root and stump system. We made a visual and acoustic evaluation (by tapping on roots) of the exposed underground of ancient stools and took cross sections of different roots. We concluded that the overwhelming majority of large roots were hollow because of heart rot or were preserved only as remnants of the original root in the form of slab roots. Because the oldest parts of the roots were decayed, the deadwood samples we were able to take could not serve as indicators of stool age. The approximated age of one of the largest oak stools at our research plots was $825 \pm 145$ years (SE). Similar or even older coppice stools of oaks and lindens with respect to size and growth rate have been reported by Rackham (2006) and Pigott (1989).

For the modeled old stool we estimated a 
ratio of 2:1 for above/below ground volume with no reduction of below ground biomass regarding the hollow roots. This is in contrast to Barbaroux et al. (2003), who found a 5:1 biomass estimation ratio in a high forest. Stem bases were clustered only at $20 \mathrm{~m}^{2}$ but the trees were spread into the neighbourhood and altogether covered a 5 times greater area than in high forest.

\section{Tree inner zone of influence}

In our study we simplified the shape of stool clusters into three categories: (I): rounded; (II): compact; (III) jagged. However, the number of variants can be very high depending on tree species: coppicing ability and strength, mortality rate and its spatial distribution, length of rotation period, longevity and rate of growth.

The present form of ancient coppices was shaped by the mortality of new shoots due to mutual competition, the ageing and dying of old stools (Larsen \& Johnson 1998, Rydberg 2000), as well as by natural habitat conditions and the length, intensity and frequency of human impact. The probability of sprouting steeply declines for stools with large DBH. If many sprouts persist on a single stump, they may develop a sweep in the lower part of the bole.

It appears that for most oak species the key factor limiting seedling recruitment is light availability, i.e. overstory crown closure. Seed regeneration is therefore far more likely in open sites away from the parent tree (Crow 1992, Dey 2002). However, with the gradual decay and dying off of ancient oak stools, one can expect an increase in seedlings of tree species other than oak (lime, hornbeam, maple, pine Szymura et al. 2014).

\section{Tree spatial patterns}

In accordance with our assumptions, stems often showed a significantly clustered distribution. This reflects the vegetative origin of stems in stools. At Lipina, stems had clustering at all study intervals up to $20 \mathrm{~m}$. A similar spatial distribution was observed in the Mondariz and Pantón coppice forests in Spain (Rozas et al. 2009). The maximum intensity of clumping in our study and in Mondariz and Pantón is almost identical, with ranges at ca. $1 \mathrm{~m}$.

Interestingly, stool centroids also showed a clustered distribution at distances to 10 $m$. This could be the effect of long-term human influence (short-rotation period). If the stems were cut at a young age (7-10, later 20 years), then the forest stand was essentially single-layered at all times. All stems needed a minimal crown area for survival, and less successful trees were gradually eliminated, so the forest stand tended towards a clustered spatial distribution.

\section{Conclusions}

For the modeled old stool we estimated a ratio of 2:1 for above/below ground volume with no reduction of below ground biomass regarding the hollow roots. The age of the largest stool was estimated 825 years \pm 145 years (SE). Total area of "Inner Zone of Influence" covers $323 \mathrm{~m}^{2} \mathrm{ha}^{-1}$. The median area of this zone in both plots was $0.40 \mathrm{~m}^{2}$ for all trees, $0.23 \mathrm{~m}^{2}$ for singles and $0.87 \mathrm{~m}^{2}$ for stools. The Matérn cluster process was successfully fitted to our empirical data. In this model the mean cluster radius ranged between 1.9 to $2.1 \mathrm{~m}$ and mean number of points per cluster was 1.7 and 1.9. The most prevalent characteristics of these ancient oak coppices were their compact shape and clustered spatial distribution up to $10 \mathrm{~m}$.

\section{Acknowledgements}

We would like to thank the Podyji $\mathrm{Na}$ tional Park Administration for supporting our research. Ivana Plačková, Dagmar Koktová, Saly Šmíd and Fidel Švejda helped us to unearth the coppice stools. Thanks to Hanuš Vavrčík from the Faculty of Forestry and Wood Technology, Mendel University in Brno for consulting the dendroecology of roots. For comments on the manuscript, we thank to Martin Valtera. David Hardekopf carried out the proofreading. This paper was created with support of projects GA CR P503-11-2301 and OPVK CZ.1.07/2.3. $00 / 20.0267$.

\section{References}

Baddeley A (2008). Analysing spatial point patterns in R. CSIRO, Australia. pp. 232. - [online] URL: http://citeseerx.ist.psu.edu/viewdoc/dow nload?doi=10.1.1.698.6837\&rep=rep1\&type=pdf Baddeley A, Turner R (2005). Spatstat: an R package for analysing spatial point patterns. Journal of Statistic Software 12: 1-42.

Barbaroux C, Bréda N, Dufrêne E (2003). Distribution of above-ground and below-ground carbohydrate reserves in adult trees of two contrasting broad-leaved species (Quercus petraea and Fagus sylvatica). New Phytologist 157 (3): 605-615. - doi: 10.1046/j.1469-8137.2003.00681.x Bauhus J (2009). Rooting patterns of old-growth forest: is aboveground structural and functional diversity mirrored belowground? In: "Old-Growth Forests: Function, Fate and Value" (Wirth C, Gleixner G, Heimann M eds). Springer, Berlin, Germany, pp. 211-229. - doi: 10.1007/978-3-540-92706-8 10

Bédéneau M, Pagés L (1984). Etude des cernes d'accroissement ligneux du système racinaire d'arbres traités en taillis. [Studies about tree rings in coppice root system]. Annales des sciences forestières 41: 59-68. [in French] - doi: 10.1051/forest:19840104

Besag J (1977). Contribution to the discussion of Dr Ripley's paper. Journal of the Royal Statistical Society (Series B) 39: 193-195.

Bruckman VJ, Yan S, Hochbichler E, Glatzel G (2011). Carbon pools and temporal dynamics along a rotation period in Quercus dominated high forest and coppice with standards stands. Forest Ecology and Management 262: 18531862. - doi: 10.1016/j.foreco.2011.08.006

Casper BB, Schenk HJ, Jackson RB (2003). Defining a plant's belowground zone of influence.
Ecology 84: 2313-2321. - doi: 10.1890/02-0287 Chytry M, Vicherek J (1995). Lesní vegetace NP Podyjí. [The Forest Vegetation in Podyjí National Park]. Academia, Praha, Czech Republic. pp. 166. [in Czech]

Coles JM (1978). Man and landscape in the Somerset Levels. In: "The Effect of Man on the Landscape: the Lowland Zone" (Limbrey S, Evans JG, eds). CBA Research Report No. 21, Council for British Archaeology, London, UK, pp. 86-89.

Copini P, Sass-Klaassen U, Den Ouden J (2010). Coppice fingerprints in growth patterns of pedunculate oak (Quercus robur). In: “TRACE Tree Rings in Archaeology, Climatology and Ecology" (Levanic T, Gricar J, Hafner P, Krajnc $\mathrm{R}$, Jagodic $\mathrm{S}$, Gärtner H, Heinrich I, eds). Otočec, Slovenia, pp. 54-60. [online] URL: http:// agris.fao.org/agris-search/search.do?recordID= NL2012006220

Crow TR (1992). Population dynamics and growth patterns for a cohort of northern red oak (Quercus rubra) seedlings. Oecologia 91: 192-200. - doi: 10.1007/BF00317783

Dey $D$ (2002). The ecological basis for oak silviculture in Eastern North America. In: "Oak Forest Ecosystems: Ecology and Management for Wildlife" (McShea WJ, Healy WM eds). The Johns Hopkins University Press, Baltimore, USA, pp. 60-79.

Diggle PJ (2003). Statistical analysis of spatial point patterns $\left(2^{\text {nd }} \mathrm{edn}\right)$. Hodder Arnold, London, UK, pp. 159

Freeman EA, Ford ED (2002). Effects of data quality on analysis of ecological pattern using the $K(d)$ statistical function. Ecology 83: 35-46. Gaertner H (2001). Holzanatomische Analyse diagnostischer Merkmale einer Freilegungsreaktion in Jahrringen von Koniferenwurzeln zur Rekonstruktion geomorphologischer Prozesse. [Wood-anatomical analysis of diagnostic characteristics of an exposure reaction in tree rings of coniferous roots to reconstruct geomorphological processes]. Rheinischen Friedrich-Wilhelms-Universität, Bonn, Germany, pp. 118. [in German]

Haneca K, Boeren I, Acker J, Beeckman H (2005). Dendrochronology in suboptimal conditions: tree rings from medieval oak from Flanders (Belgium) as dating tools and archives of past forest management. Vegetation History and Archaeobotany 15: 137-144. - doi: 10.1007/s003 34-005-0022-x

Haneca K, Cufar K, Beeckman H (2009). Oaks, tree-rings and wooden cultural heritage: a review of the main characteristics and applications of oak dendrochronology in Europe. Journal of Archaeological Science 36: 1-11. - doi: 10.1016/j.jas.2008.07.005

Hölscher D, Schade E, Leuschner C (2001). Effects of coppicing in temperate deciduous forests on ecosystem nutrient pools and soil fertility. Basic and Applied Ecology 164: 155-164. doi: 10.1078/1439-1791-00046

Itô H, Hino T, Sakuma D (2012). Species abundance in floor vegetation of managed coppice and abandoned forest. Forest Ecology and Management 269: 99-105. - doi: 10.1016/j.for eco.2011.12.017

Janík D, Vrška T, Samonil P, Unar P, Adam D, Hort L, Král K (2007). Structure and Ecology of 
oak woods in the Podyji National Park as exemplified by the Lipina locality. Thayensia 7: 175206.

Jeník J (1957). Korenový systém dubu letního a zimního: rhizologická studie. [Root system of oaks]. Nakladatelství CSAV, Praha, Czech Republic. pp. 85. [in Czech]

Jeník J, Soukupová L (1999). On the growth form of bog pine, Pinus $\times$ pseudopumilio. Silva Gabreta 3: 25-32. [online] URL: http://www.nps umava.cz/gallery/8/2457-sg3 jeniksoukupova .pdf

Joys A, Fuller RJ, Dolman PM (2004). Influence of deer browsing, coppice history, and standard trees on the growth and development of vegetation structure in coppiced woods in lowland England. Forest Ecology and Management 202: 23-37. - doi: 10.1016/j.foreco.2004.06.035 Král K, Valtera M, Janík D, Šamonil P, Vrška T (2014). Spatial variability of general stand characteristics in central European beech-dominated natural stands - Effects of scale. Forest Ecology and Management 328: 353-364. - doi: 10.1016/j.foreco.2014.05.046

Kull K (1995). Growth form parameters of clonal herbs. Consortium Masingii: A Festschrift for Victor Masing, Tartu, Estonia, pp. 106-115. [online] URL: http://archive.is/fhPS

Lang S, Tiede D (2003). vLATE Extension für ArcGIS - vektorbasiertes Tool zur quantitativen Landschaftsstrukturanalyse [vLATE - Vector-based Landscape Analysis Tools Extension for ArcGIS\}. In: Proceedings of the Conference "ESRI Anwenderkonferenz" [ESRI User-conference]. Innsbruck (Austria) 8-10 Oct 2003. [CDROM] [in German] [online] URL: http://www. researchgate.net/publication/258892081

Larsen DR, Johnson PS (1998). Linking the ecology of natural oak regeneration to silviculture. Forest Ecology and Management 106: 1-7. - doi: 10.1016/S0378-1127(97)00233-8

Loosmore NB, Ford ED (2006). Statistical inference using the $\mathrm{G}$ or $\mathrm{K}$ point pattern spatial statistics. Ecology 87: 1925-1931. - doi: 10.1890/001 2-9658(2006)87[1925:SIUTGO]2.0.CO;2

McGarigal K, Marks BJ (1995). Fragstats: spatial pattern analysis program for quantifying landscape structure, version 2.0. Oregon State University, Corvallis, USA, pp. 134.
Nadezhdina N, Cermak J (2003). Instrumental methods for studies of structure and function of root systems of large trees. Journal of Experimental Botany 54: 1511-1521. - doi: 10.1093/ jxb/erg154

Neruda P (2007). Starší doba kamenná v Podyjí: Současný stav a perspektivy [Old stone age in the river Dyje region: an overview and perspectives]. Thayensia 7: 291-303. [in Czech]

Nielsen AB, Møller F (2008). Is coppice a potential for urban forestry? The social perspective. Urban Forestry and Urban Greening 7: 129-138. doi: 10.1016/j.ufug.2008.02.005

Peterken GF (1996). Natural woodland: ecology and conservation in northern temperate regions. Cambridge University Press, Cambridge, UK, pp. 540. [online] URL: http://books.goo gle.com/books?id=p3y43NnvXPYC

Pigott CD (1989). Factors controlling the distribution of Tilia cordata Mill. at the northern limits of its geographical range. IV. Estimated ages of the trees. New Phytologist 112: 117-121. - doi: 10.1111/j.1469-8137.1989.tbo0316.x

R Development Core Team (2015). R: a language and environment for statistical computing. $R$ Foundation for Statistical Computing, Vienna, Austria. [online] URL: http://www.R-project.org Rackham O (2006). Woodlands. Collins, London, UK, pp. 608.

Reiterová L, Skorpík M (2012). Plán péče o Národní park Podyjí a jeho ochranné pásmo. [Management plan for Podyjí National Park and its protective zone]. Správa NP Podyjí, Znojmo, Czech Republic, pp. 316. [in Czech]

Ripley BD (1977). Modelling spatial patterns. Journal of the Royal Statistical Society (Series B) 39: 172-212. [online] URL: http://www.jstor. org/stable/2984796

Rozas V, Zas R, Solla A (2009). Spatial structure of deciduous forest stands with contrasting human influence in northwest Spain. European Journal of Forest Research 128: 273-285. - doi: 10.1007/s10342-009-0263-9

Rydberg D (2000). Initial sprouting, growth and mortality of European aspen and birch after selective coppicing in central Sweden. Forest Ecology and Management 130: 27-35. - doi: 10.1016/S0378-1127(99)00187-5

Schweingruber FH (2007). Wood structure and environment. Springer, Berlin, Heidelberg, Germany, pp. 279. [online] URL: http://books.goo gle.com/books?id=t5fVEqRnyjoC

Stoyan D, Penttinen A (2000). Recent applications of point process methods in forestry statistics. Statistical Science 15: 61-78. - doi: 10.1214/ ss/1009212674

Szymura TH, Szymura M, Pietrzak M (2014). Influence of land relief and soil properties on stand structure of overgrown oak forests of coppice origin with Sorbus torminalis. Dendrobiology 71: 49-58. [online] URL: http://yadda. icm.edu.pl/yadda/element/bwmeta1.element.a gro-aab41ba7-9562-4bod-8454-b5201af7d7b6/ c/9.pdf

Tolasz R (2007). Atlas podnebí Ceska. [Climate atlas of Czechia]. Czech Hydrometeorological Institute, Praha, Czech Republic, pp. 255. [in Czech]

Verheyen K, Bossuyt B, Hermy M, Tack G (1999). The land use history (1278-1990) of a mixed hardwood forest in western Belgium and its relationship with chemical soil characteristics. Journal of Biogeography 26: 1115-1128. - doi: 10.1046/j.1365-2699.1999.00340.x

Vrška T (1998). Historický vývoj lesu na území NP Podyjí a v bližším okolí do roku 1948. [Historical development of forests in Podyjí National Park until 1948]. Thayensia 1: 101-124. [in Czech]

Vyskot M (1961). Výsledky neprímých prevodu parezin pretvárením. [The results of coppice transformation management]. Lesnictví 12: 1061-1096. [in Czech]

Walker J, Sharpe PJ, Penridge LK, Wu HI (1989). Ecological field theory: the concept and field tests. Vegetatio 83: 81-95. - doi: 10.1007/BFooo3 1682

Weber P, Bardgett RD (2011). Influence of single trees on spatial and temporal patterns of belowground properties in native pine forest. Soil Biology and Biochemistry 43: 1372-1378. - doi: 10.1016/j.soilbio.2011.03.015

Wu HI, Sharpe PJ, Walker J, Penridge LK (1985). Ecological field theory: a spatial analysis of resource interference among plants. Ecological Modelling 29: 215-243. - doi: 10.1016/0304-3800 (85)90054-7 